\title{
Interruptions: Derrida and Hospitality
}

\section{Mark W. Westmoreland}

C

ome in. Welcome. Be my guest and I will be yours. Shall we ask, in accordance with the Derridean question, "Is not hospitality an interruption of the self?"1 What is the relationship between the interruption and the moment one enters the host's home? Derrida calls us toward a new understanding of hospitality-as an interruption. This paper will illuminate the history of hospitality in the West as well as trace Derrida's discussions of hospitality throughout many of works. The overall goal of this project is to provide readers of Derrida with a sort of reference guide for his discussions on and deconstructive approach to hospitality.

Throughout most of Derrida's work, there lurks an oasis of hospitality, sometimes on the verge of the horizon. At other times, it shines in the foreground. It is in these shining moments that we-both host and guestwill venture in order to grasp the foundation of Derrida's thoughts on hospitality. Only then will we clearly see the horizon. This new understanding of hospitality requires a rethinking of the laws of common, conditional hospitality in contrast with the law, or perhaps we should say ethics, of unconditional hospitality. Hent de Vries comments on this relationship: "Absolute hospitality ... and the hospitality of rights and laws ... must always exist in a relation of subordination, or justification, with one enabling the other." 2

On the one hand, the only hospitality that we have ever encountered in the West has been conditional. Conditional hospitality concerns itself with rights, duties, obligations, etc. It has a lineage tracing back to the GrecoRoman world, through the Judeo-Christian tradition, and to the political philosophies of Kant and Hegel. ${ }^{3}$ It has been regulated. Moreover, as Michael Naas points out, "For when it comes to politics, to hospitality in or of the state, conditions are always stipulated." 4 Hospitality has always been juridical.

This tradition, the one we have inherited, stretches back to ancient Greece in particular. The hospitality of ancient Greece was understood in relation to the

\footnotetext{
${ }^{1}$ Jacques Derrida, Adieu, trans. by Pascale-Anne Brault and Micheal Naas (Stanford: Stanford University Press, 1999), 51. 2002), 304.

${ }^{2}$ Hent de Vries, Religion and Violence (Baltimore: The Johns Hopkins University Press,

3 Jacques Derrida, Of Hospitality, trans. by Rachel Bowlby (Stanford: Stanford University Press, 2000), 77.

${ }^{4}$ Michael Naas, Taking on the Tradition: Jacques Derrida and the Legacies of Deconstruction (Stanford: Stanford University Press, 2003), 157.
} 


\section{INTERRUPTIONS}

law. (However, let us not forget that the law, as a human construction, is not resistant to deconstruction. $)^{5}$ In Athens, the foreigner [xenos] held some rights. Moreover, he was identified according to a pact [xenia]. Derrida writes, "Basically, there is no xenos, there is no foreigner before or outside the xenia." An individual was recognized by how he appeared before the law, what status he held in the polis. The foreigner was placed inside the law, under the law, essential to the law. The foreigner occupied an integral space within the city. Indeed, the foreigner was essential because he provided that to which citizens could compare themselves. From a phenomenological standpoint, one could claim that one's identity is only understood in relation to others. Citizens understand themselves in relation to others, to foreigners. "We are not those sorts of people. We are citizens." In the laws of hospitality, we find a multiplicity involving differentiation according to the right of the state. The state establishes rules through which people can be divided into citizens and non-citizens, citizens and foreigners, hosts and guests. It can identify individuals; and therefore, it can include or exclude whosoever it chooses based on the laws, which it has created. For example, ancient Athens determined citizenship according to one's place of birth. Socrates was, no doubt, a citizen of Athens; whereas, Aristotle, being born in Stagira, could never have become a citizen. Also, as Derrida points out, Socrates claimed to be a foreigner while appearing before the Athenian court.

In addition to its association to the law, hospitality has been reciprocal, engaged in an economy of exchange, even an economy of violence-this will be discussed later. In other words, an exchange takes place between the host and the guest. In offering hospitality, in welcoming the other, the host imposes certain conditions upon the guest. First, the host questions and identifies the foreigner. "What is your name? Where are you from? What do you want? Yes, you may stay here a few nights." Secondly, the host sets restrictions. "As my guest, you must agree to act within the limitations I establish. Just don't eat all my food or make a mess."

On the other hand, "Ethics," Derrida writes in a discussion on Levinas, "is an ethics without law and without concept."7 Robert Bernasconi argues, "And the possibility of ethics is referred, not to its actuality, but to its impossibility." 8 Any law or concept would impose on hospitality and would cause it to no longer be absolute, or unconditional. In Adieu to Emmanuel Levinas, Derrida defines ethics as hospitality, hospitality as ethics. Hospitality is not removed from ethics, nor is it a specific area of ethics. It is the foundation, or "the whole and the principle of ethics." In other words, ethics relies on hospitality so much that one cannot speak of ethics without speaking of

\footnotetext{
${ }^{5}$ See Force of Law: The "Mystical Foundation of Authority."

${ }^{6}$ Derrida, Of Hospitality, 29.

7 Jacques Derrida, Writing and Difference, "Violence and Metaphysics," trans. by Alan Bass (Chicago: University of Chicago Press, 1978), 111.

${ }^{8}$ Robert Bernasconi, "Deconstruction and the Possibility of Ethics," in Deconstruction and Philosophy, ed. by John Sallis (Chicago: University of Chicago Press, 1988), 135.

${ }^{9}$ Derrida, Adieu, 50.
} 
hospitality, although the relationship between the two may be at once both hidden and calling to be seen.

Hospitality is also defined as culture. Like ethics, there is no culture without hospitality. "Hospitality," Derrida claims, "is culture itself and not simply one ethic among others." 10 This absolute hospitality rests outside of right, above that which is juridical. Unlike conditional hospitality, it is not associated with right, with law, with debt, or with duty. Samuel Weber claims that "the problem of the law can be formulated, accordingly, as that of translating an unconditional promise into a conditional one." 11 Moreover, it cannot be undone or altered by something outside of itself. Hospitality, as absolute, is structured as a universal singularity, without imperative, order, or duty. It blankets over all and is not bound by any other ethical imperative except for itself. Furthermore, it is the condition for the possibility of hospitality - the hospitality that we have always known. The law of hospitality is absolute in that it requires one to give all one has to another without asking any questions, imposing any restrictions, or requiring any compensation. Absolute hospitality involves neither the governance of duty nor the payment of debt. It is in this sense that hospitality is absolute, "unconditional but without sovereignty."12 If there is an imposition, nothing is left to be called absolute. In our finitude, we grasp hospitality in terms of its limitations. Hospitality is never fully open; there is always some violence.

Operative between the self and the other, hospitality governs all human interaction (and perhaps interaction with animals as well). According to Levinas, hospitality is "the concrete and initial fact of human recollection and separation."13 An aporia: hospitality, which demonstrates deconstruction's insufficiency insofar as deconstruction's work is never quite finished. Absolute hospitality is both "inconceivable and incomprehensible."14 Furthermore, Derrida writes:

The law of hospitality, the express law that governs the general concept of hospitality, appears as a paradoxical law, pervertible and perverting. It seems to dictate that absolute hospitality should break with the law of hospitality as right or duty ....15

10 Jacques Derrida, On Cosmopolitanism and Forgiveness, trans. by Mark Dooley and Richard Kearney (New York: Routledge, 2005), 16.

11 Samuel Weber, "In the Name of the Law," in Deconstruction and the Possibility of Justice, ed. by Drucilla Cornell, Michel Rosenfeld, and David Gray Carlson (New York: Routledge, 1992), 251.

12 Derrida, On Cosmopolitanism and Forgiveness, 59.

13 Emmanuel Levinas, Totality and Infinity, trans. by Alphonso Lingis (Pittsburgh: Duquesne University Press, 1969), 172.

14 Jacques Derrida, Acts of Religion, "Hostipitality," trans. by Gil Anidjar (New York: Routledge, 2002), 362.

${ }^{15}$ Derrida, Of Hospitality, 25. 


\section{INTERRUPTIONS}

Absolute hospitality can only exist as unlimited, as not being within the parameters of laws and concepts. The conditions for such hospitality are both the conditions for its possibility and its impossibility.

Absolute hospitality's very being unconditional means that there can be no debt or exchange involved. If hospitality is demonstrated to another solely out of duty or by law, then it is not absolute hospitality. Such hospitable acts remain conditional. Commenting on Kierkegaard, Derrida states that if duty is obeyed "only in terms of duty, I am not fulfilling my relation to God."16 This duty to God, according to Kierkegaard, is the ultimate duty. Nor is it partially and simply concerned with "the right of a stranger" as Kant suggests. According to Kant, hospitality is limited to the rights of the visitor "not to be treated with hostility when he arrives on someone else's territory," not the rights of the resident, which must be established by and between political sovereignties. ${ }^{17}$ Furthermore, the laws of hospitality are bound up with the state as sovereign, as that which determines laws and duty. ${ }^{18}$ Absolute hospitality, however, involves that which is beyond duty and right. It is "law without law," and here is the distinction between "an unconditional law or an absolute desire for hospitality [and] a law, a politics, a conditional ethics". ${ }^{19}$ The guest must be free of any subordination or debt.

Derrida's discussion centers within the home, in the relationship between the master, or host, and the guest, the foreigner, the hostis. Throughout his corpus, Derrida illustrates this relationship by giving examples such as Oedipus, Abraham, Lot, Socrates, and those foreigners who enter cities of refuge. His examples cross over from characters of fiction to contemporary political situations, from ancient Greece to the Middle East, from monotheisms to immigration policies. In all of his examples, this relationship of host and guest is ever present. Hospitality: welcome. Quasi-synonyms. ${ }^{20}$

We are now at the threshold of the home. "Toward the inside (hospitality)—deconstruction," argues Leonard Lawlor, "concerns itself with the limit or the threshold." 21 In "Hostipitality," Derrida claims, "Hospitality is the deconstruction of the at-home; deconstruction is hospitality to the other." 22 The master of the home, the host, must welcome in a foreigner, a stranger, a guest, without any qualifications, including having never been given an invitation. Such an invitation as a host offering his or her home to a guest implies a sort of exchange between the two- "the most inhospitable exchange possible." 23 In order to offer unconditional hospitality, the master must not

\footnotetext{
16 Jacques Derrida, The Gift of Death, "Whom to Give to," trans. by David Willis (Chicago: University of Chicago Press, 1996), 63.

17 Immanuel Kant, Perpetual Peace, trans. by H.B Nisbet (New York: Cambridge University Press, 1991), 105.

18 See Derrida, On Cosmopolitanism and Forgiveness, 20-23.

${ }^{19}$ Derrida, Adieu, 83; Of Hospitality, 147.

${ }^{20}$ See Ibid., 45.

${ }^{21}$ Leonard Lawlor, Derrida and Husserl (Indianapolis: Indiana University Press, 2002),

22 Derrida, Acts of Religion, "Hostipitality," 364.

${ }^{23}$ Ibid., 398.
} 
allow for any debt or exchange to take place within the home. No invitation, or any other condition, can ever be a part of absolute hospitality. Hospitality, as absolute, is bound by no laws or limitations.

The host freely shares her home with the new arrival without asking questions. She neither asks for the arrival's name, nor does she seek any pact with the guest. Such a pact would instigate the placing of the guest under the law. The law of absolute hospitality does not involve an invitation, nor does it involve an interrogation of the guest upon entering. Indeed, there is no need for speech, only silence. Derrida argues that the language of hospitality "appeals to the other without condition." 24 The host must not even ask for a proper name or any sort of identification like Darwish's identity card. ${ }^{25}$ Should one demand that his guest be able to communicate in a foreign language, which is usually "the first violence to which foreigners are subjected?"26 In discussing Socrates as a foreigner, Derrida asks, "Must we ask the foreigner to understand us, to speak our language . . . in all its possible extensions, before being able and so as to be able to welcome him into our country?"27 The Athenians placed Socrates on trial and questioned him in the language of the courts, which was foreign to him. Socrates did not know the legal rhetoric of the courts and could not speak as an equal, but only as a foreigner. However, absolute hospitality relies upon the deafening silence between the ipse and the other. The host bequeaths a smile and welcomes the other without asking any questions that would qualify as conditions for hospitality. In The Gift of Death, Derrida writes, "The first effect or first destination of language therefore involves depriving me of, or delivering me from, my singularity." 28 Once the host speaks, he is no longer himself, "alone and unique." He has committed an inhospitable act against himself. When (conditional) hospitality is given, it is accompanied with laws - the rules and codes of language, which are shared among human beings. Common hospitality involves linguistic communication, which requires the distinction between individuals to be stripped away, and cancels the possibility of having an unconditional hospitality.

Before the arrival of the guest, the master, or host, of the house was in control. In Rogues, Derrida recalls that ipse often refers to a host. ${ }^{29}$ It would be assumed that the host secures the house in order to "keep the outside out" and

\footnotetext{
24 Jacques Derrida, Sovereignties in Question, "Rams," trans. by Thomas Dutoit and Outi Pasanen (New York: Fordham University Press, 2005), 153.

${ }^{25}$ Mahoud Darwish is a Palestinian poet who wrote the poem "Identity Card" about losing one's personal identity. The name of the Arab in the poem is not given. According to his identity card, he is known only as a number.

26 Jacques Derrida, Paper Machine, "The Principle of Hospitality," trans. by Rachel Bowlby (Stanford: Stanford University Press, 2005), 68. See Acts of Religion, "Force of Law," 245-246.

${ }^{27}$ Derrida, Of Hospitality, 15.

${ }^{28}$ Derrida, The Gift of Death, "Whom to Give to," 60.

29 See Jacques Derrida, Rogues, trans. by Pascale-Anne Brault and Michael Naas (Stanford: Stanford University Press, 2005), 10.
} 


\section{INTERRUPTIONS}

holds authority over those who may enter the home as guests. ${ }^{30}$ Derrida writes that hospitality cannot be "without sovereignty of oneself over one's home, but since there is also no hospitality without finitude, sovereignty can only be exercised by filtering . . . and doing violence." 31 Limits and conditions are set in place to secure the ipse as master of the house. As such, these conditions betray the law of absolute hospitality.

Interruptions. That which makes unconditional hospitality possible also allows for the impossibility of hospitality. Derrida, in Of Hospitality, writes the beginning of our "formulation":

To put it in different terms, absolute hospitality requires that I open up my home and that I give not only to the foreigner, but to the absolute, unknown, anonymous other, and that I give place to them, that I let them come, that I let them arrive, and take place in the place I offer them, without asking of them either reciprocity (entering into a pact) or even their names. ${ }^{32}$

Absolute hospitality allows for violence. A new arrival, or guest, stands at the door, at the border, and is welcomed inside without condition. This very welcoming opens up into a violence. Such violence turns the home inside out. "A host is a guest," writes J. Hillis Miller, "and a guest is a host." 33 The host becomes the guest. Likewise, the guest becomes the master of the home. The "formula" continues:

. . . the bote who receives (the host), the one who welcomes the invited or received the hote (the guest), the welcoming hote who considers himself the owner of the place, is in truth a hote received in his own home. He receives the hospitality that he offers in his own home; he receives it from his own home-which, in the end does not belong to him. The hote as host is a guest. ${ }^{34}$

In other words, Derrida claims that "we thus enter from the inside: the master of the house is at home, but nonetheless he comes to enter his home through the guest-who comes from outside." 35 In welcoming the guest, the self is interrupted.

30 Jacques Derrida, Dissemination, "Plato's Pharmacy: The Pharmakos," trans. by Barbara Johnson (Chicago: University of Chicago Press, 1981), 128. Compare our "formula" for hospitality to Derrida's discussion of the Pharmakon and Khora.

31 Derrida, Of Hospitality, 55.

32 Ibid., 25. Italics by Derrida.

33 J. Hillis Miller, "The Critic as Host," in Deconstruction and Criticism (New York: Continuum, 1985), 221. In this text, Miller emphasizes the role of the critic as host and applies a deconstructive approach to literary criticism.

${ }^{34}$ Derrida, Adieu, 41. Italics by Derrida.

${ }^{35}$ Derrida, Of Hospitality, 125. 
A tension arises. In order to be hospitable, the host must rid himself of security and invite the new arrival. The ipse gives up security, authority, and property and promises benevolence. The guest becomes the host. Thus, absolute, unconditional hospitality is never possible in conjunction with indivisible sovereignty. The host may be characterized as if he were sovereign in that "a pure sovereignty is indivisible or it is not at all" and yet, the host relinquishes sovereignty to the guest. ${ }^{36}$ For example, in the Torah, Lot champions the laws of hospitality over his obligation to protect his own family. When the Sodomites come to Lot's house and demand that he offer up his guests to them, Lot offers his two virgin daughters in the stead of his guests. ${ }^{37}$

The authority of the host has diminished. The "formula" that we have been developing concludes:

So it is indeed the master, the one who invites, the inviting host, who becomes the hostage-and who really always has been. And the guest, the invited hostage, becomes the one who invites the one who invites, the master of the host. The guest becomes the host's host. The guest (bote) becomes the host (hote) of the host (bote)..$^{38}$

The host has welcomed into his home the very thing that can overturn his sovereignty. In welcoming the new arrival, the host has brought about that which takes him hostage. In Otherwise than Being or Beyond Essence, Levinas writes, "The subject is hostage." 39 The ipse as a host has been interrupted. The guest has taken over the home and the master has become hostage. To put it another way, the host has been substituted for the guest.

Derrida notes that all three Abrahamic monotheisms share Abrahamic hospitality in common. These three religions share similar stories of Abraham and his sacrifice. Abraham took his son Isaac to an altar provided by God outside of the city and was to sacrifice his son out of fear and in obedience. However, God provided a substitution for Isaac and spared him. ${ }^{40}$ Derrida describes the test of substitution:

To be one at the place of the other, the hostage and the hote of the other; therefore the subject of the other, subject to the other, there where not only cannot places be exchanged-insofar as they remain unexchangeable

\footnotetext{
36 Derrida, Rogues, 101

${ }^{37}$ Genesis 19. See Derrida, Adieu, 94. There is, attached to hospitality, a role of the feminine. Compare Khora, as it refers to the feminine, with the two virgin daughters of Lot.

${ }^{38}$ Derrida, Of Hospitality, 125.

${ }^{39}$ Emmanuel Levinas, Otherwise than Being or Beyond Essence, trans. by Alphonso Lingis (The Hague: Martinus Nijhoff, 1981), 112.

40 Who or what exactly the substituted individual was differs between Islam and Judaism and Christianity. See Surah 37 and Genesis 22.
} 


\section{INTERRUPTIONS}

and where everything withdraws from a logic of exchange-but where this unicity, this irreplaceability of the nonexchange poses itself, affirms itself, tests and suffers itself, in substitution. ${ }^{41}$

Hospitality involving both hostage and substitution is most clearly seen in this classic example of Abraham.

Hospitality: an aporia, an impossibility. In reflecting on Levinas, Derrida writes, "I must welcome the infinite, and this is the first hospitality, beyond the capacity of the I-which is obviously the impossible itself." 42 It appears as though the law of unconditional hospitality and the laws of hospitality conflict with one another. However, the two are irreducible to one another nonetheless. The law of hospitality opens up the possibility for contamination in that it calls for no governing body such as a sovereign state or master of a home to establish laws and authority over another subject. The state or master retains the capacity to be overthrown. The laws of hospitality strongly rely upon laws and duty, or adherence to the law. These laws attempt to ensure the preservation of a state or master. Derrida questions the relationship between the two meanings:

It is as though the laws (plural) of hospitality, in marking limits, power, rights, and duties, consisted in challenging and transgressing the law of hospitality, the one that would command that the 'new arrival' be offered an unconditional welcome. ${ }^{43}$

It seems as if the laws of conditional hospitality and the law of unconditional hospitality conflict with one another. Do the laws transgress the law of hospitality? Does the law of hospitality demand a transgression of the laws? They are not symmetrical, equally opposing one another. Rather, a hierarchy exists in which the law is above the laws, outside the laws. However, the two complement each other in that the law of hospitality requires the laws so as to not be abstract. ${ }^{44}$ Peggy Kamuf writes:

To think the unconditionality of such concepts is not at all to remove thought from the practical experiences we wish to call hospitality, gift, forgiveness, or justice. On the contrary, this thinking registers the very desire to go on calling to these names for that which remains impossible as present experience..$^{45}$

\footnotetext{
${ }^{41}$ Derrida, Acts of Religion, "Hostipitality," 387.

42 Ibid., 386.

${ }^{43}$ Derrida, Of Hospitality, 77.

${ }^{44}$ See Ibid., 79.

45 Peggy Kamuf, "From Now On,” in Epoche, 10:2 (Spring 2006), 207.
} 
The laws of hospitality receive inspiration from the law. These laws and the law of hospitality simultaneously include and exclude one another. Furthermore, hospitality remains "inconceivable and incomprehensible" and "becomes possible but as impossible," yet it "remains impracticable."46 And yet, the two are forever inseparable.

Perhaps this new understanding of hospitality will encourage a rethinking of related themes such as iterability, promise, democracy, fraternity, and forgiveness. ${ }^{47}$ Derrida asks us to think beyond the limits of philosophy. He stretches us to think beyond the limits of Kantian hospitality, to grasp the Levinasian distinction between the self and the other, and to challenge the aporia of hospitality. He invites us to challenge our ideas on sovereignty and immigration. Throughout Derrida's writing on hospitality, a call is sounded-a call to see the unity of the Abrahamic monotheisms and to establish their role in the discussion of the law of hospitality. Most importantly, we must embrace hospitality as an interruption-an interruption of the self. Exit.

Department of Philosophy, Neumann College, United States

\section{References}

Bernasconi, Robert, "Deconstruction and Possibility of Ethics," in Deconstruction and Philosophy: The Texts of Jacques Derrida, ed. by John Sallis (Chicago: University of Chicago Press, 1988).

de Vries, Hent, Religion and Violence: Philosophical Perspectives from Kant to Derrida (Baltimore: The Johns Hopkins University Press, 2002).

Derrida, Jacques, Acts of Religion, trans. by Gil Anidjar (New York: Routledge, 2002).

, Adieu, trans. by Pascale-Anne Brault and Micheal Naas (Stanford: Stanford University Press, 1999).

, Dissemination, trans. by Barbara Johnson (Chicago: University of Chicago Press, 1981).

, The Gift of Death, trans. by David Willis (Chicago: University of Chicago Press, 1996).

, Of Hospitality, trans. by Rachel Bowlby (Stanford: Stanford University Press, 2000).

, On Cosmopolitanism and Forgiveness, trans. by Mark Dooley and

Richard Kearney (New York: Routledge, 2005).

Paper Machine, trans. by Rachel Bowlby (Stanford: Stanford University Press, 2005).

Rogues, trans. by Pascale-Anne Brault and Michael Naas (Stanford: Stanford University Press, 2005).

46 Derrida, Acts of Religion, "Hostipitality," 387; Paper Macbine, "Not Utopia, the ImPossible," 131. See Adien, 21

${ }^{47}$ See Derrida, Limited Inc. See Paper Machine, "As If It Were Possible, 'Within Such Limits," 87. See also Derrida's discussions of democracy and fraternity, which are discussed in Rogues and The Politics of Friendship respectively. 


\section{INTERRUPTIONS}

, Sovereignties in Question, trans. by Thomas Dutoit and Outi Pasanen (New York: Fordham University Press, 2005).

,Writing and Difference, trans. by Alan Bass (Chicago: University of Chicago Press, 1978).

Kamuf, Peggy, "From Now On," in Epoche, 10:2 (Spring 2006), 203-220.

Kant, Immanuel, Perpetual Peace, trans. by H.B Nisbet (New York: Cambridge University Press, 1991).

Lawlor, Leonard, Derrida and Husserl: The Basic Problem of Phenomenology (Indianapolis: Indiana University Press, 2002).

Levinas, Emmanuel, Otherwise than Being or Beyond Essence, trans. by Alphonso Lingis (The Hague: Martinus Nijhoff, 1981).

, Totality and Infinity, trans. by Alphonso Lingis (Pittsburgh: Duquesne University Press, 1969).

Miller, J. Hillis, "The Critic as Host," in Deconstruction and Criticism (New York: Continuum, 1985).

Naas, Michael, Taking on the Tradition: Jacques Derrida and the Legacies of Deconstruction (Stanford: Stanford University Press, 2003).

Weber, Samuel, "In the Name of the Law," in Deconstruction and the Possibility of Justice, ed. by Drucilla Cornell, Michel Rosenfeld, and David Gray Carlson (New York: Routledge, 1992). 